\title{
先天性垂直性眼振症例と文献的考察
}

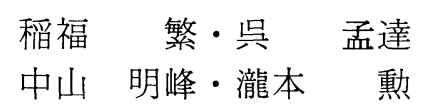

\section{Congenital Vertical Nystagmus; A Case Report}

\author{
Shigeru Inafuku, Men-dar Wu, Meiho Nakayama \\ and Isao Takimoto
}

(Aichi Medical University)

\begin{abstract}
Although congenital vertical nystagmus is very rare, we treated on 6-year-old girl who had spontaneous eye movements and myopia. Down beat nystagmus was noted on forward gaze, and it increased in amplitude and frequency on downward gaze. The nystagmus disappeared when her eyes were closed in a lighted room and when her eyes were open in a dark room.

Eye tracking tests for slow and quick components in the horizontal plane were normal. Optokinetic nystagmus in the horizontal plane was within normal limits. Normal caloric responses were observed. No vertical optokinetic nystagmus was induced. The patient had complete loss of the slow pursuit function in the vertical plane. Therefore, we considered this to be a case of congenital vertical nystagmus due to a disturbance of the slow pursuit system of vertical eye movements.
\end{abstract}

Key words: congenital, vertical nystagmus, loss of slow pursuit function

はじめに

めまい外来において，先天性眼振は特に稀な あのではない. しかし，その多くは水平性眼振 であり，先天性垂直性眼振は極めて稀でかつ文 献的報告も少ない，我々は，6歳女子で先天性 垂直性眼振と思われる症例を経験したので報告 する.

\section{症例}

Y. H. 女性, 6 歳.

主訴：視力障害, 眼が動く.

既往歷：特記事項なし。

家族歴：図 1 亿示す如く，近親者に先天性水 平性眼振と䛦断されたものあり.
現病歷及び生育歷：出生時体重 $3160 \mathrm{~g}$ 満期 産, 安産であり特に鉗子分婏や分婏時異常はな い. 又, 母親は妊娠中に，特に感染性疾患の既往 はなく, 薬物, アルコール等の服用もない. 出生 後の発育も良好で, 新生児黄㾝も殆ど認めなか った. 話し始めは約 8 力月, 歩き始めは約一年, 幼稚園での生活は順調で知的発育や運動能力の 発達に異常を認めなかった。 小学校入学後の眼 科検診にて視力異常を指摘され, 愛知医科大学 眼科を受診した. 眼科にて，弱視及び眼振を指 摘され，当日耳鼻科へ紹介された.眼振について は両親ともに気付いてなく, 当大学受診時に指 摘されて初めて知った. しかし，後述の如く， 
テレビを見る時に顎をひいて上目使いに見てい た事は幼少時より母親は気付いていたが，単に 癖だろうと特に気にとめなかったとの事である。

眼科所見：角膜，瞳孔，虹彩飞異常なく， 眼底も異常を認めなかった. 視力は右眼 0.2 (0.3), 左眼 $0.3(0.4)$ で, 矯正できない弱視 であった。

一般的所見：身長 $104 \mathrm{~cm}$, 体重 $25 \mathrm{~kg}$, 普通 学級 1 年生, 特に異常を認めない，四肢等に神 経的異常所見なし.

耳鼻科所見：耳，鼻，咽喉頭に異常所見なし， 聴力は純音聴力で異常なく, tone decay や耳小

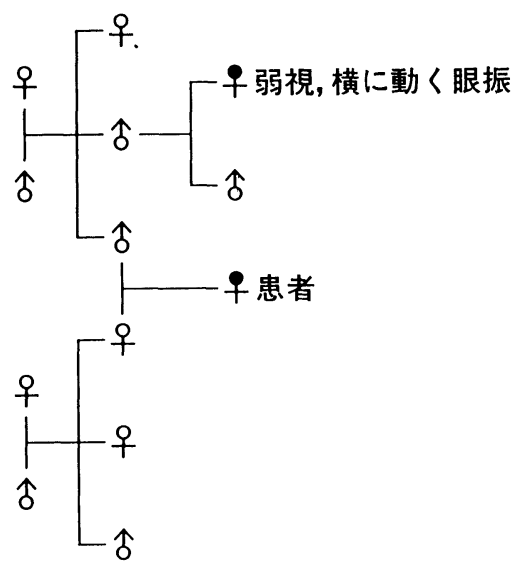

図 1 家族歷
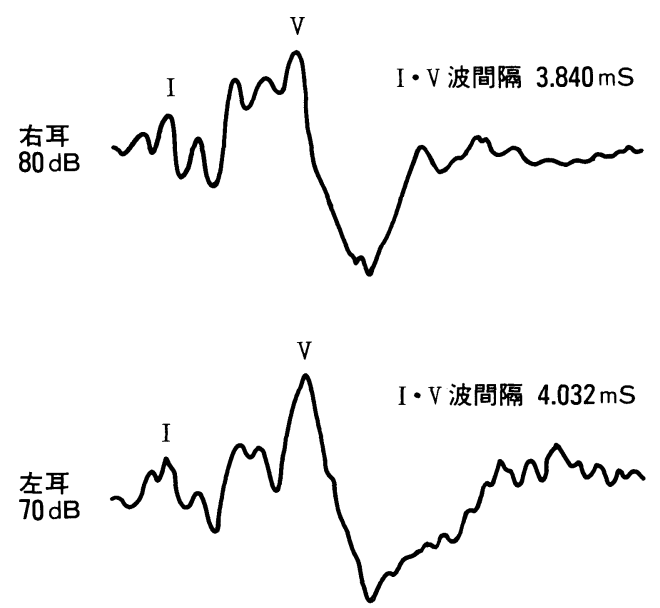

図 2 聴性脳幹反応
骨筋反射は正常範囲であった。聴性脳幹反応は 図 2 に示す如く I $\sim V$ 波共に明瞭で I $\sim V$ 波間 隔は正常であった。

平衡機能検査 : 立ち直り反射は開閉眼共に良 好で，重心動摇計に示す如く特に異常を認めな かった（図 3 ). 注視眼振は図 4 に示す如く,左 右側方視の場合でも垂直性の眼振があり，特に 下方視の際は下眼瞼向きの component が強く なったが，上方視では眼振は消失するか，かな り弱くなった. 肉眼的に counterrolling や oculocephalic reflex はともに正常な反応か認めら れた。また Frenzel 眼鏡を装着すると裸眼注視 に比し眼振は弱くなり，さらに閉眼や遮眼さら にボーッと前方を見る姿勢や暗所開眼では眼振 は殆ど消失した，乙れらの注視眼振記録及び自 発眼振記録を図 5 に示した。正面注視における 垂直性眼振は，急速相と緩徐相の差が少なく， 部分的には pendular type を示す事むあったが，

\section{重心動摇図}
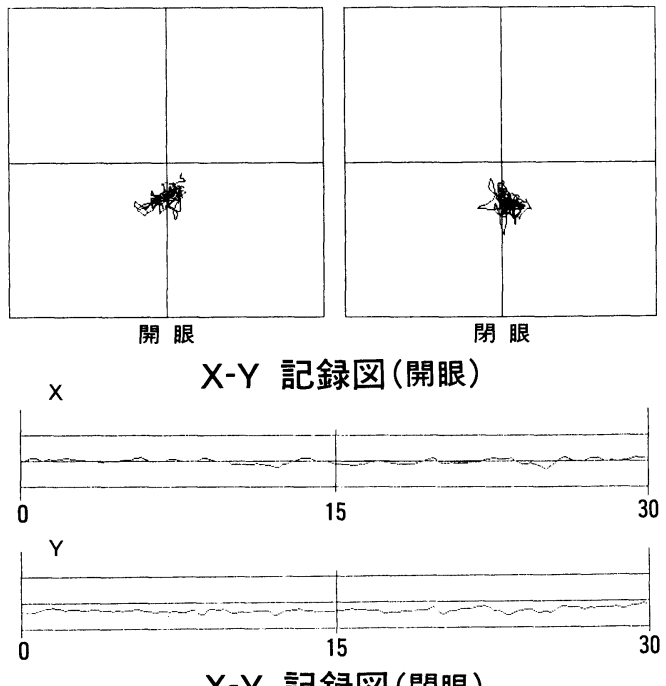

X

$X-Y$ 記録図 (閉眼)

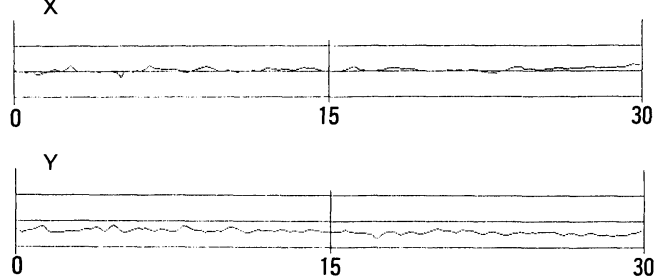

図 3 


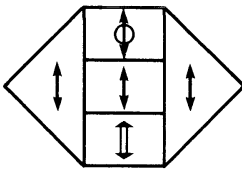

注視指示で眼振は著明に
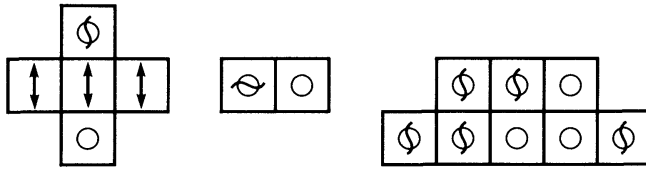

Frentzel 眼鏡下では, 眼振がなくなるか 不規則に出現

図 4 注視眼振，頭位眼振検査
その振幅は 3 度から 5 度， 1 分間に 2 打から 3 打，両眼共同性であった。下方視では下眼瞼向 きの jerky type に変化し，その際に最む強く観 察され，その振幅は 5 度から 6 度，1 分間に約 60打の頻度であった.

図6は，温度眼振記録である。 air caloric $20^{\circ} \mathrm{C}$ にて右耳 80 犁，左耳 85 秒でほぼ同程度の 水平性眼振反応を示し, slow component, quick component 共によく誘発されていた.

図 7 は，水平成分の眼運動検査記録である. 眼球運動急速相検査 (saccadic pursuit) では特 に ocular dysmetria や眼運動の緩徐化は認め ていない。また，緩徐相検査 (smooth pursuit,

\section{眼運動記録}

暗所開眼,「ボーッと前を見る」時も同

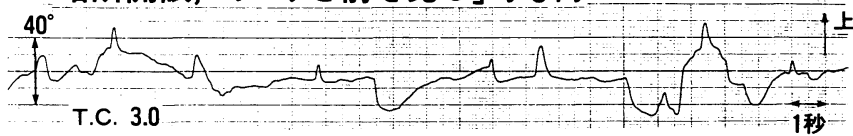

\section{正面視}
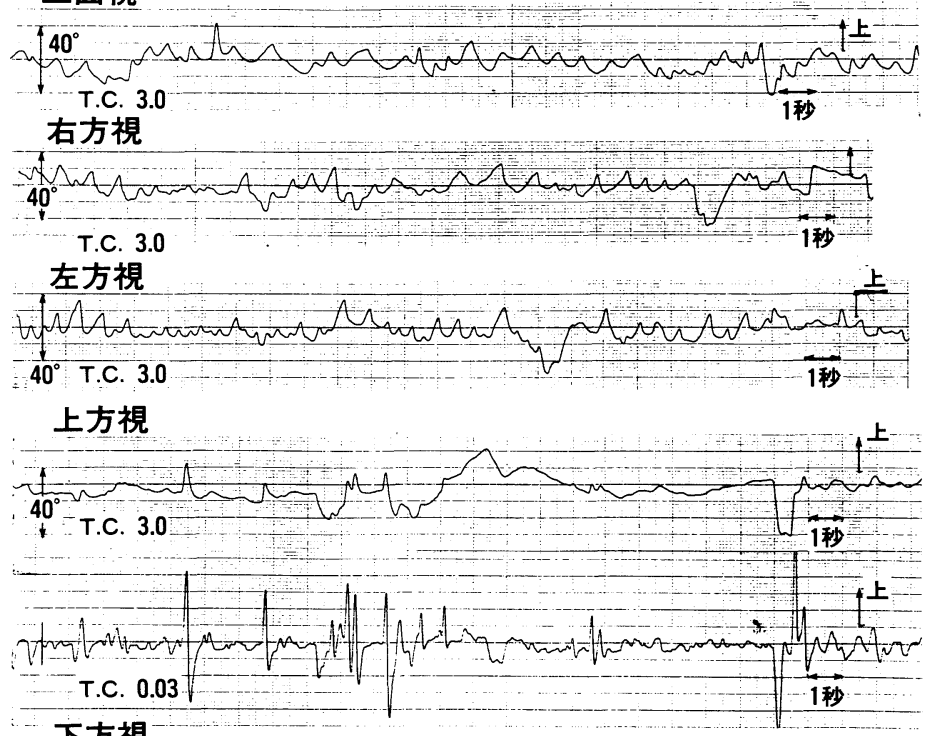

下方視

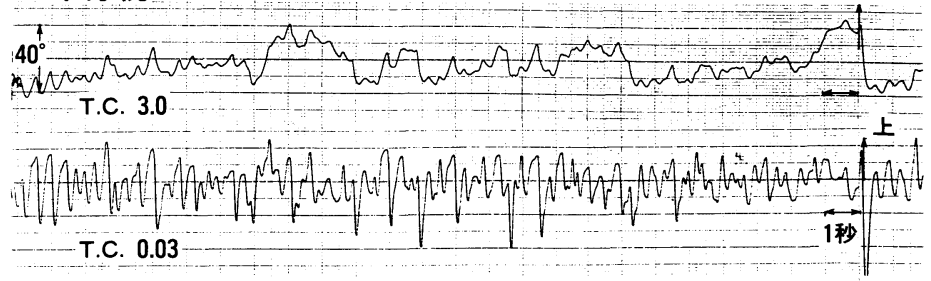

図 5 
ETT) は，ほぼ視標通り追跡できた.ただし， 注視による垂直性眼振が常に見られるので， ETT はやや smoothさを欠いていたが，本
例では水平成分に異常を認めないと判定した OKP 法ではわずかに総眼振数の低下を認めた. OKNで示す如く, 水平成分の slow component

\section{温度眼振検查 $\left(20^{\circ} \mathrm{C}\right.$ air $)$}

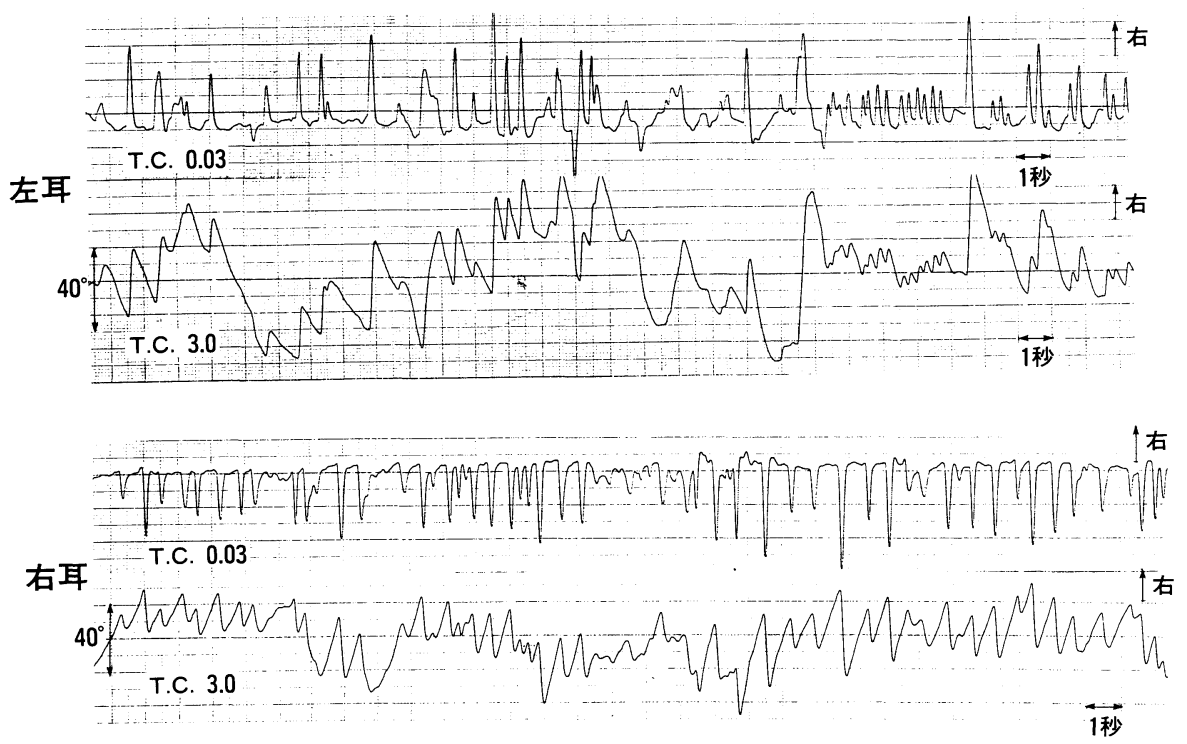

図 6

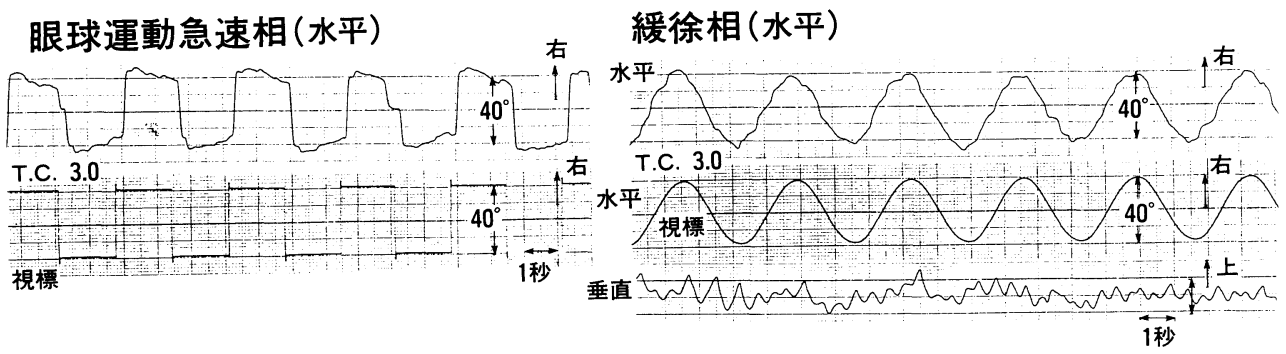

\section{視運動性眼振 (水平)}

右OKP

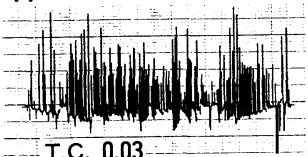

左OKP

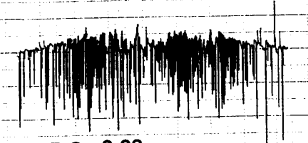

T.C. 0.03

\section{右OKN}

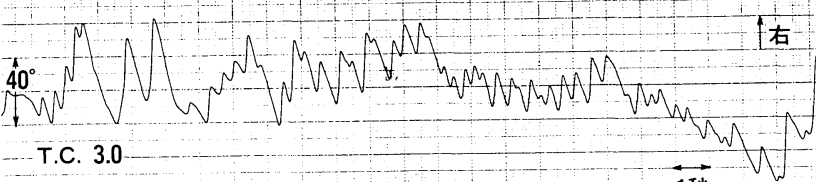

左OKN

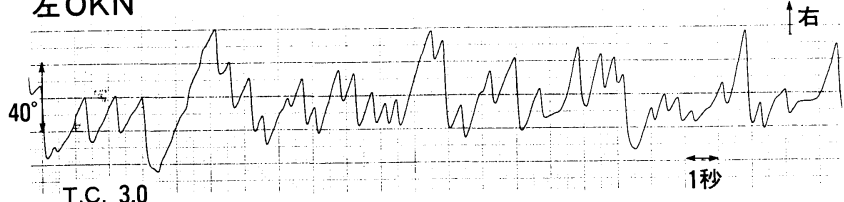

図 7 
は，概ね正常である事が判明した。

図 8 は垂直成分の眼運動検査である。眼球運 動急速相は，自発眼振が superimpose してい たが，矢印の如く quick component は明確に 観察できた。しかし，自発眼振と同期して視標 が移動したりする場合ああり, quick component が正常であるとは言えない，又，緩徐相成分 は本例が先天性と判断した最も重要な検査項 目であるが，罒に示す如く slow component は 全く欠如していた。 この事は OKN であ明確 であり，視運動性刺激には上下共に無反応で あったＯKP 法でわずかに上 OKP で inversion 状に出ていたが，元々上下への slow component が欠如しているので，inversion とは言 えない.

\section{考案}

先天性眼振の報告は最近 10 年間だけでも 100 編を越える報告がある。しかしその多くが先天 性水平性眼振である. 水平性を念頭においた先 天性眼振の診断基準は，坂田 ${ }^{1)}$ によれば，1） 例外はあるが，一般的には生後まあなく，ある
いは幼少時期に何らかの機会に眼振を発見され ている，2）眼振は高頻度であり，遮眼，閉眼 で抑制される。また，開眼時と遮眼時とで眼振 方向の変化するすのがある. 3）動摇視がない 4）眼振のための視力障害があり，矯正不能の 事が多い. 5) 眼振以外に神経学的異常を欠く. 6）遺伝関係を有するあのがある．7）母親の妊 娠中，出産時に異常を伴うものがある．8）視 運動刺激にたいして異型反応（全錯倒，一側錯 倒，一部錯倒，その他），無反応走す。等で ある. 小松崎 ${ }^{2}$ あほぼ同様の特徴を述べている が他に，「交代性眼振 nystagmus alternans や 潜伏性眼振 nystagmus latens の形をとるとと がある」や，「指標追跡検査では，常に円滑な 眼球運動の障害が認められている」としている。 先天性垂直性眼振についての記載では「主と して眼球緩徐相と急速相の速度の差が大でない。 oscillopsia を伴わず，また，他の神経症状も伴 わない」としている. Cogan ${ }^{3)}$ あ「先天性ある いは遺伝性眼振は誕生後からあり，視力障害や 明確な神経疾患に原因せず良性の進行しない状
眼球運動急速相 (垂直)

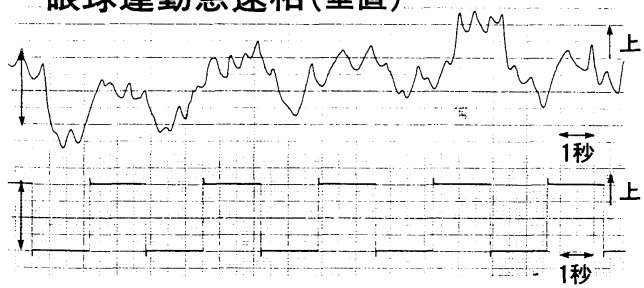

\section{緩徐相 (垂直)}

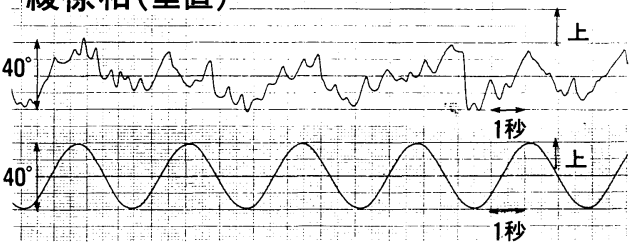

\section{視運動性眼振 (垂直)}

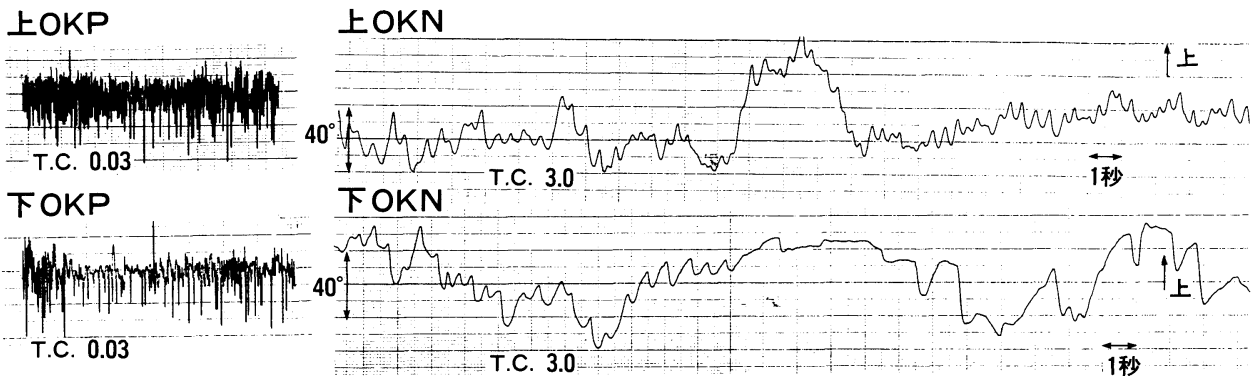


表 1 先天性垂直性眼振症例

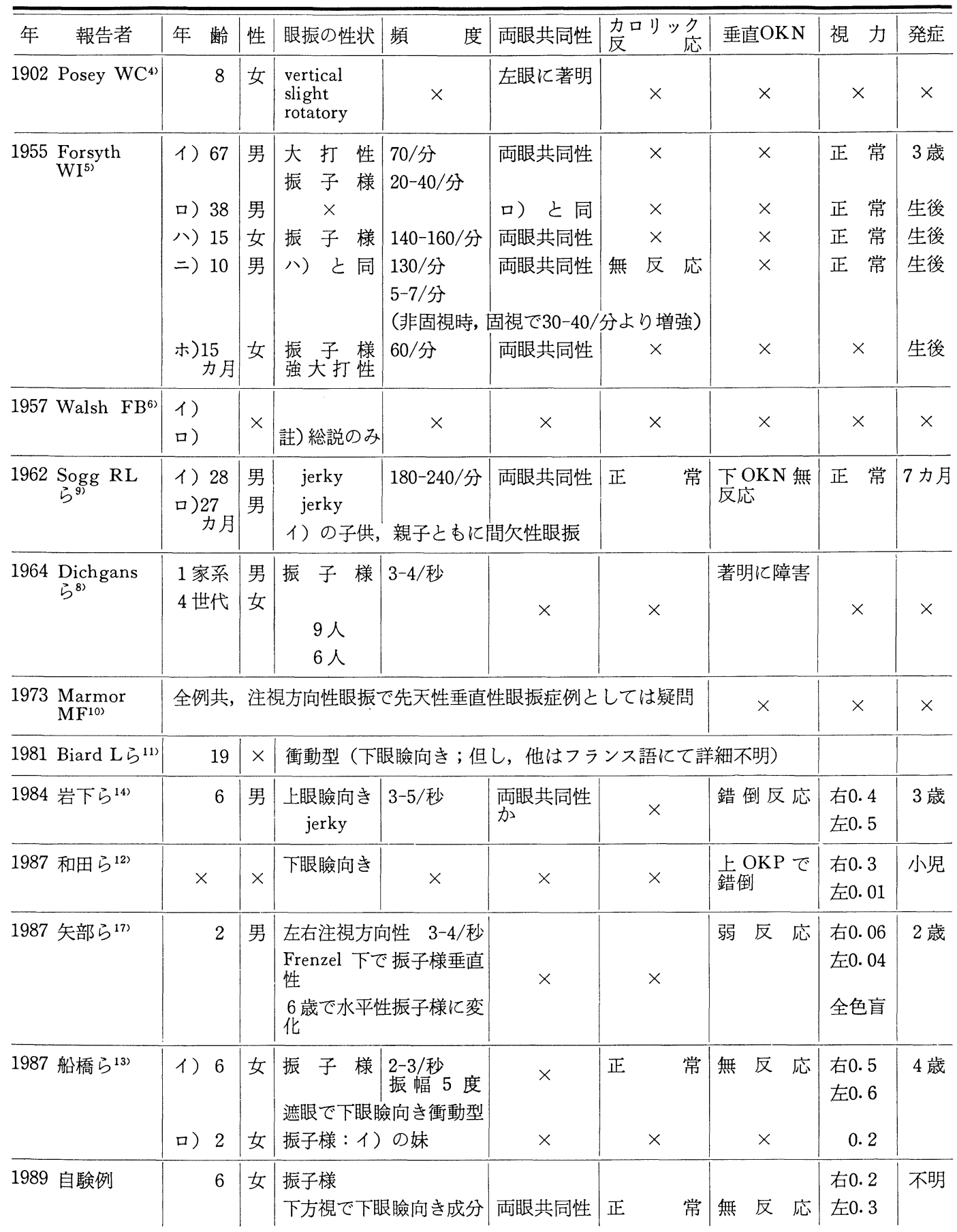

×印：記載なし 
態である. OKN には障害か無反応を呈し， 高頻度に斜視や astigmatism が関与している」 と述べている. しかし先天性垂直性眼振は極め て稀で我々が渉猟し得た範囲では，報告例は表 1 亿示すように10編のみだった．先天性垂直性 眼振を最初に報告したのは，1902 年のPosey ${ }^{4)}$ で頭振を伴う小児例を報告しているが，滑動性 眼運動の状況や視運動刺激にたいする反応につ いては記載していない。1955年 Forsythe ${ }^{5)}$ は先 天性遺伝性垂直性眼振の 5 症例を呈示し，全 5 例と屯遺伝性之猃断している。，その眼振は全例 と屯振子様眼振で両眼共同性で，頻度は 1 分間 に60から160と色々あるが，特に第 4 例は通常 報告されている先天性眼振の概念之背反する. すなわち「固視により眼振は減少し，固視して いない時にゆっくりとした頻度 ( 5 〜 / 分) か ら高頻度 $(30 \sim 40 /$ 分 $)$ に変化し，短時間では あるが自分で眼振を止める事ができる」という 所見を呈示している. これは随意性眼振との移 行を含め興味ある所見である.Forsythe ${ }^{5)}$ の報告 で滑動性眼運動検查や視運動性眼振の検討はし ていなく, 本症例の病変部位については全例剖 検をしていないので不明と述べている.Walsh' ${ }^{6)}$ は 2 例呈示しているが第 2 例は下眼瞼向衝動型 で視運動刺激に対し無反応としていて，我々の 症例に近いが，成書に打ける先天性（垂直性） 眼振の綜説なので，詳細な検討はされていない， ただ Bender と Gorman ${ }^{7)}$ の説を引用し，「垂 直性眼振は多くの例で脳幹障害を合併している. おそらく小脳虫部の病変が源だろう」としてい るが，種々の神経症状を持つ後天性眼振の病変 部位を直接先天性と同一視してよいか，な抬検 討を要する. Dichigans と Kornhuber ${ }^{8)}$ は 4 世 代にわたって15人屯先天性眼振がみられた一家 系の垂直性眼振を呈示し，垂直性視運動性眼振 が著明に障害されていたと報告している，眼振 の性状は多くは振子様で時に上眼瞼向きの衝動 型を呈したという.

1962年 Sogg とHoyt" ${ }^{9}$ は父子にみられた間 歇型垂直性眼振症例を報告した。そそれによれば
両者と屯上眼瞼向きの著明な両眼共同性眼振を 1 時間から 2 時間半にわたり呈し, 発作時, 非 発作時共に何の障害も示さず，ただ oscillopsia を自覚している，子供の異常眼運動は生後 2 日 で発見されている事より随意性眼振とは異なり， 視力の発育段階早期に出現している。 また父親 は水平性視運動眼振には正常反応を示したが, 上方回転の視運動性眼振（下 OKN）には無反 応で，下方回転では視運動性眼振が発現し，温 度眼振には正常反応を示したとしている。下 OKN 無反応は先天性眼振とする重大な根拠で あろうが，視標を追跡できたか否かについては 記載がない，極めてまれな症例であるが，脳幹 の生来の遗伝性核上性障害と類推している. Marmor ${ }^{10)}$ は，遺伝性垂直性眼振症例として 3 家系計 9 例を報告しているが，全例ともいわゆ る注視方向性眼振と何らかの神経徴候（症例 1 . broad-based, 症例 2 . unsteadiness, 症例 3 . broad based gait 等) を有し, 先天性垂直性眼 振とするには疑問の症例である. 全症例共に左 右注視ではすべて水平性眼振で, 上方視では垂 直性眼振か，下方視での下眼瞼向き眼振を示し ている. 注視方向性眼振から脳幹障害を示唆し ている事は承諾できるが，多くの例で水平性視 運動性眼振の機能低下や欠如がある事より, 歩 行障害等の神経症状を呈する遺伝性小脳脳幹障 害の一型であろうと思われる．他にBiard ら ${ }^{11)}$ ， 和田ら ${ }^{12)}$ の報告があるが，詳細は不明である。 船橋ら ${ }^{13)}$ は 6 歳と 2 歳の姉妹に発現した垂直性 振子様眼振を報告している. 6 歳児では垂直性 の振子様眼振（振幅 5 度, 頻度 $2 \sim 3 \mathrm{~Hz}$ ) を呈 し, 閉眼では全く消失, 垂直性 $\mathrm{ET} T$ 異常, 垂 直性 OKN 無反応, カロリックテスト正常, 之抄録に記載し, 更に水平性 $\mathrm{OKN}$ あほぼ正 常範囲の様で視力障害（右0.5, 左0.6）が主訴 である事から我々の症例之酷似している.

先天性水平性眼振では, 視運動性眼振に対し て錯倒現象や無反応が診断上の重要な根拠 ${ }^{122}$ と提唱されているが, 先天性垂直性眼振につい ては特に記載がなかった。最近岩下ら ${ }^{14)}$ は「先 
天性垂直性自発眼振」確実例として 6 歳児の症 例を報告し，その診断根拠として「垂直性視運 動刺激に対して錯倒現象を示す」事を重要な点 として挙げている. 一方, 栄木 ${ }^{15)}$ は先天性眼振 106例中垂直性は 4 例（衝動型）としているが， OKN 検査にて錯倒 (inversion) を呈するあのが 見られなかったと記している。しかし ENG 記録の呈示はない。時田 ${ }^{16)}$ は，垂直性眼振に $\mathrm{OKN}$ 錯倒はないと記しているが症例呈示むな いので，根拠は不明である．小松崎”は，神経 症候を伴う垂直性眼振と比較して一例を示し， 診断に関する要点を記載しているが，滑動性眼 運動障害とはしていない。

最近，矢部ら ${ }^{17)}$ は全色盲を伴い初診時には垂 直性であった眼振が， 1 歳 6 力月より 5 年間の 観察の中で斜行性から水平性振子様眼振汇変化 していった症例を報告し, $\operatorname{Cogan}^{3)}$ の言う運動 障害性眼振之診断している. 矢部らの例では ENG 記録による水平, 垂直 OKP は共に極め て解発が悪く, 前者では部分的な錯倒を示し, また滑動性眼運動（ETT）は水平，垂直共に自 発眼振が重なり saccadic pattern を示した。 こ の事実から眼運動系は水平, 垂直共に障害され ている事は確かであるが, 眼振方向が変化した 事も含め, その病変部位については, 既知の後 天性垂直性眼振の責任病巣や垂直注視中枢之の 関連付けはできなかったと述べている. 同一患 者で垂直性より水平性眼振に移行している点で かなり重要な示唆を与える症例である.

先天性眼振の責任病巣については, 諸家の報 告では前庭第一次反射弓より中枢のなんらかの 障害であろうと推察されている( ${ }^{518)}$. 栄木 ${ }^{15)}$ は, 従来の脳幹障害説に加うるに広く小脳錐体系を 中心に，中脳，間脳錐体系の障害によって発現 して来るあのであろうと推察している.しかし， 剖検例がそしい事ああり, 明確に病変部を特定 する事は難しいと考える. 我々の症例の如く, 他に神経学的異常所見を呈せず，知能，運動能 力共に正常に発育している例については責任部 位を論ずる事は困難である. 垂直性眼球運動中
枢としては Cajal 核の吻側, Darkschwitsch 核 の腹側にあるrostral interstitial nucleus of MLF が考えられているが(19)，我々の例では CT 上は 異常が検出できなかった.

本論文で最も強調したい点は，第一に先天性 垂直性眼振では, 先天性水平性眼振が滑動性眼 運動障害を呈するのと同様に，垂直性滑動性眼 運動が高度に障害されている事であり，乙れ が診断の根拠になりうるあのと考える. Dell' $\mathrm{Osso}^{20)}$ も水平性眼振の分析において, 指標追 跡運動の障害が先天性眼振の原因である事を示 唆している，第二に本例でみると水平系眼運動 はほとんど冒されていないので垂直系は別の神 経系統の障害である事を示している，乙の所見 は船橋 ${ }^{13)}$, 岩下ら ${ }^{14)}$, Dichigans $ら^{8)}$ と類似し ている. 垂直性から水平性に移行した矢部らの 例から見て，先天性眼振では水平性，垂直性の 病変部位が近傍にあるか否か, 今後の剖検的研 究が待たれる. 第三に, 先天性眼振は近親者に 屯認められる事が多く，本例の近親者も水平性 眼振を示し，年龄と共に減弱した。

なお岩下ら ${ }^{14)}$ は錯倒現象を診断の重要なポイ ントとしているが，我々の例は上下 OKP で上 下差はあったものも錯倒とはせず，無反応とし た。これは下眼瞼向き自発眼振が強く, 本来出 現すべき刺激を行っても，自発眼振のみが記録 されている状況であり，かつ視運動刺激による 緩徐相が出現しない為, 無反応となった。

基本的には滑動性眼運動障害が先天性垂直性 眼振の診断における最む重要な点であろうと思 われた。

\section{まとめ}

先天性垂直性眼振の幼览症例について報告 した.

1 ) 症例は 6 歳女坚で，特に他に神経学的徵 候を持たず，知能，運動能力共に正常であった

2）眼振は大打性で頻度は 1 分間に70〜80打 数で，下眼瞼向きの方向性を帯びていたが，注 視方向により振子様の所見もあった，また，眼 振急速相と緩徐相の差は少なかった。眼振は閉 
眼, 暗所開眼, 眼前をボーッと見る際等にほと んど見られなくなり，Frenzel 眼鏡下で抑制さ れた.

3）水平系の眼運動では, 自発性垂直性眼振 により滑動性眼運動記録にわずかな Notch を 示したが，視運動性眼振と共にほぼ正常範囲で あった。

4) 特徵的所見亡して, 垂直系眼運動記録で は急速眼運動は認めたが，緩徐相即ち滑動性眼 運動は全く欠如していた。垂直性視運動刺激に は無反応であった。

本論文の要旨は, 第56回日耳鼻東海地方部会で口演 した.

\section{参考文献}

1）坂田英治：臨床神経耳科学入門. 57 61頁, 医歯 薬出版, 東京, 1980 .

2) 小松崎篤 : 眼球運動の神経学. 288頁, 306 311 頁, 医学書院, 東京, 1985.

3) Cogan DG: Congenital nystagmus. Can J Ophthalmol $2: 4 \sim 10,1967$.

4) Posey WC: Associated movements of head and eyes. JAMA $39:$ 1365 1367, 1902.

5 ) Forsythe WI : Congenital hereditary vertical nystagmus. J Neurol Neurosurg-Psychiat 18:196 $\sim 198,1955$.

6) Walsh FB: Clinical Neuro-Ophthalamology, 2 ed. pp 268 269, Williams and Willkins, Baltimore, 1957.

7) Bender MB and Gorman WF : Vertical nystagmus on direct forward gaze with vertical oscillopsia. Am J Ophthalmol 32 : 967 972, 1949.

8) Dichigans J and Kornhuber HH : Eine sertene Art des hereditären Nystagmus mit autosomal dominanten Erbgang und besondern Erscheinungsbild; Vertical Nystagmus Komponente und Störung des Vertiscben Nystagmus. Acta Genet
$14: 245 \sim 250,1964$.

9) Sogg RL and Hoyt WF : Intermittent vertical nystagmus in a father and son. Arch Ophthalmol $68: 515 \sim 517,1962$.

10) Marmor MF : Hereditary vertical nystagmus. Arch Ophthalmol $90: 107 \sim 111,1973$.

11) Biard L, Nicol G and Moynat B : Nystagmus vertical congenital. Bull Soc Opht France 81 : 1005 1008, 1981.

12）和田昌士, 岩本幸江：先天性垂直性眼振の 1 症 例. 日耳鼻 $90: 1424,1987$.

13）船橋利理, 薮本充雄, 中井三量, 他 : 姉妹に発現 した先天性垂直性振子様眼振 2 症例. 眼臨医報 $81: 423,1987$.

14）岩下菜穂子, 中沢 宏, 大都京子, 他：いわゆる 「先天性垂直性眼振」確実例. Equilibrium Res $43: 76 \sim 82,1984$.

15）栄木恭男：いわゆる「先天性特発性眼振」の病態 生理補遺. 日耳鼻 $77: 8 \sim 45,1974$.

16）時田 喬: 神経耳科学 II. 177頁, 金原出版, 東京, 1985 .

17）矢部多加夫, 加我君孝, 児玉和夫 : 先天性垂直性 眼振の 1 症例. 耳喉 $59: 947 \sim 953,1987$.

18) Forssmann B : A study of congenital nystagmus. Acta Otolaryngol $57:$ 427 449, 1963.

19) Buttner-Ennever JA and Buttner U : A cell group associated with vertical eye movement in rostral mesencephalic reticular formation of the monkey. Brain Res $151: 31 \sim 47,1978$.

20) Dell'Osso LF : Congenital nystagmus; Basic aspects. Functional Basis of Ocular Mortility Disorders (ed by Lennerstrand G, Zee DS and Keller EL). Pergamon Press, Oxford, 1982.

$$
\begin{aligned}
& \text { 原稿受付 : 平成元年 } 5 \text { 月 } 26 \text { 日 } \\
& \text { 原稿採択 : 平成元年 } 7 \text { 月 } 25 \text { 日 } \\
& \text { 別刷請求先 : 稲福 繁 } \\
& \text { T480-11 愛知県愛知郡長久手町 } \\
& \text { 大字岩作字碓又21 } \\
& \text { 愛知医科大学耳鼻咽喉科学教室） }
\end{aligned}
$$

